\title{
Evaluation method of economic efficiency of industrial scale research based on an example of coking blend pre-drying technology
}

\author{
Piotr Żarczyński ${ }^{1, *}$, Andrzej Strugała ${ }^{2}$, and Krzysztof Kwaśniewski ${ }^{3}$ \\ ${ }^{1}$ Arcelor Mittal Poland S.A. Zdzieszowice Unit, Poland \\ ${ }^{2}$ AGH University of Science and Technology, Faculty of Energy and Fuels, Cracow, Poland \\ ${ }^{3}$ AGH University of Science and Technology, Faculty of Management, Cracow, Poland
}

\begin{abstract}
The research on new and innovative solutions, technologies and products carried out on an industrial scale is the most reliable method of verifying the validity of their implementation. The results obtained in this research method give almost one hundred percent certainty although, at the same time, the research on an industrial scale requires the expenditure of the highest amount of money. Therefore, this method is not commonly applied in the industrial practices. In the case of the decision to implement new and innovative technologies, it is reasonable to carry out industrial research, both because of the cognitive values and its economic efficiency. Research on an industrial scale may prevent investment failure as well as lead to an improvement of technologies, which is the source of economic efficiency. In this paper, an evaluation model of economic efficiency of the industrial scale research has been presented. This model is based on the discount method and the decision tree model. A practical application of this proposed evaluation model has been presented based on an example of the coal charge pre-drying technology before coke making in a coke oven battery, which may be preceded by industrial scale research on a new type of coal charge dryer.
\end{abstract}

\section{Introduction}

The development and level of knowledge have a key meaning for the progress of a civilization. In particular, the development of scientific knowledge has a significant impact on the technological, social and economic progress of societies and countries. However, the availability of scientific knowledge is limited to experts, due to its fragmentation and specialization also in the scope of the same discipline. The empirical studies are particularly important in business activities. They allow for the practical application of the theoretical research results by developing methods and techniques that can be used in production processes and, consequently, for the creation of innovations [7].

According to statistics, only a small part of the initial ideas, approx. $1-2 \%$, is suitable for further consideration and then for application in the economy. For this reason, while

\footnotetext{
* Corresponding author: piotr.zarczynski@arcelormittal.com
} 
conducting the scientific research focused on the innovations development, it is extremely important to engage in the study both the scientific institutions and the economic ones, as this helps in their practical orientation from the very beginning. Conducting research is related to large expenditures and therefore many enterprises are reluctant to engage in research activities. Usually, they focus their strategies on the acquisition of certain technologies which are available on the market. At the same time, they lose the chance to become a pioneer of innovation in the area of their activities, and thereby also the opportunities to gain exceptional economic benefits [1].

The best way to conduct the research related to new and innovative solutions, technologies or products is to carry out the entire research cycle including the basic (theoretical), laboratory and implementation (industry) research. Especially this last stage includes the transfer of results of basic and laboratory research on an industrial scale - the transition from models and prototypes to the mass production phase. It requires the highest involvement of the entities, thus incurring the research costs and creating the need to take the risk of obtaining unfavorable results. At the same time, they give an almost 100 percent certainty of the results.

In the case of the decision to implement new and innovative technologies, it is reasonable to carry out industrial research, both because of the cognitive values and its economic efficiency. Research on an industrial scale may prevent investment failure as well as lead to technologies improvement, which is the source of economic efficiency. Further on in the paper, an evaluation model has been presented of economic efficiency of the industrial scale research based on the discount method and the decision tree model.

\section{Evaluation method of economic efficiency of industrial scale research}

In the case of investment decisions concerning complex investment projects, the decision tree method can be applied. In the first place, it is useful in the case of projects implemented sequentially, that is, when the decisions form a decision chain. Therefore, the risk occurs only at certain times during the investment implementation. An example of such a decision may be a decision to conduct an industrial research. Decisions taken in the next and successive moments depend on the results achieved so far. The decision tree method allows one to structure the complex problems and develop their graphical presentation in the decision tree form which contains the most important moments in a chronological order [11]. Figure 1 represents an example of a decision tree.

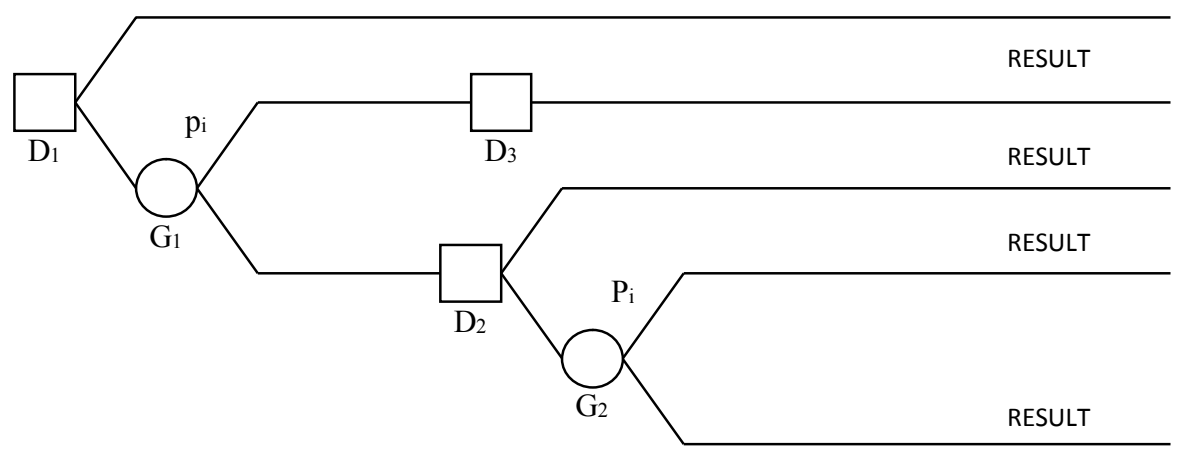

Fig. 1. Decision tree model $\left(D_{i}-\right.$ decision node, $G_{i}$, - chance node, $p_{i}-$ probability $\left.i\right)$. 
The decision tree consists of decision nodes and chance nodes. The decision nodes represent the possible ways of action at a given moment and the decision-maker makes a choice. The chance nodes are the beginning of the branches describing the consequences of decisions taken by the decision-maker which depend only on the external environment. It is necessary to determine expenditures related to potential decisions, the value and distribution of cash flow over time as well as the their probability of obtaining. It is possible to quantify the value of future decisions, the total probability and measurement of risk expressed through standard deviation. Very complex decision trees can take a vague shape and transform into over-complex trees with a significant number of decisions possible to be undertaken and with a significant number of possible results. Therefore, the application of this method for very complex projects can be problematic. The correct determination of the probability of each solution is particularly important and difficult. In the case of the decision tree elaborated for the investment project including industry research, the determination of the probability of good results can be performed by way of an cexpert analysis, using the results of the earlier research stages.

Each of the branches and decision nodes is characterized by cash flows and expenditures realted to the undertaken decisions. The determination of their value and distribution in time is necessary for evaluating the project value for the investor with the use of discount methods. In recent years, during the economic efficiency evaluation of the investment project (calculating the NPV), the Free Cash Flow approach (FCF) is applied, which takes into account in a better way the operational profit achieved by the company in relation to capital cost and investors' expectations. Free cash flows can be defined as a surplus or deficit of cash that may be a result of operating or investing activities undertaken by a company, after satisfying all the financial expectations of entities financing the activities (donors of capital). So, free cash flows are the surplus or shortage of cash generated as a result of business activities after deducting all expenses (except expenses of the debt, but after taxation), at the disposal of entities financing the company (owners and creditors) $[11,14]$.

The above methodology has been used to evaluate the economic efficiency of the industrial research of the coal charge pre-drying before the coking process for the investment project taking into consideration the implementation of this operation in an existing coking plant.

\section{Case study}

Unceasing efforts aimed at improving the economic efficiency of coke production are made in the coke-making industry. On the one hand, they have to meet increasingly higher quality requirements of the coke customers, and, on the other, they lead to the achievement of competitive advantage. The dominant cost item in the coke production is the cost of the coking coal blend. Therefore, the activities aiming at the coal blend cost reduction without the coke quality deterioration are sought. One of such activities is coal charge pre-drying implementation, which allows one to reduce the coking coal blend cost due to the possibility of increasing the share of semi-soft coals (Polish type 34) - it is the main source of economic benefits $[2,3,6]$.

\subsection{Characteristics of coal charge pre-drying operation}

The Coking coal charge pre-drying operation is the optimized version of coal blend thermal treatment. It involves the controlled pre-drying of the blend (to the temperature cir. $85^{\circ} \mathrm{C}$ ), which causes a partial removal of its moisture - from cir. $9 \%$ to cir. $5 \div 6 \%$. The coking 
process including the pre-drying operation includes two stages. At the first stage, which takes place before charging a blend to the oven, the blend is pre-dried in a special device designed for this purpose. At the second stage, i.e. after charging the thermally treated blend to the oven, the essential coking process takes place [2].

The implementation of the coal charge pre-dring provides a number of technological advantages, of which the most important are $[2,3,6,12,16]$ :

- increased coal blend bulk density in the chamber after its charging,

- shorter charging time of the chambers,

- increased production capacity of a coke battery,

- higher durability of the battery's brickwork,

- improvement of the homogeneity of the bulk density distribution for the entire height and length of the oven,

- improvement of coke making properties of the coal blend

- constant moisture content in the coal blend, independent of atmospheric conditions,

- better quality of coke produced on the basis of an unchanged coal blend,

- possibility to utilise the waste heat produced in coking plant,

- improvement of the energy efficiency of the general coking process and, consequently, a reduction of the unit emissions to the environment (including $\mathrm{CO} 2$ ),

- a wider product range offered by the coke plant,

- improvement of the coking plant production flexibility by obtaining the opportunities for active management of production capacity (production capacity diversification of the coke oven battery depending on the decision to start or stop the pre-drying installation).

The technological benefits arising from the coal charge pre-drying implementation can be used in two competing directions:

- improvement in the quality of coke produced on the basis of the current coal blend,

- increase in the share of semi-soft coals (with worse coking properties) in blends without deterioration of the quality of resulting coke.

The first direction is quite commonly used in coking plants in the countries of the Far East (Japan, South Korea, China) with the use of the technology called CMC (Coal Moisture Control) [8]. In Polish conditions, this second direction is particularly interesting, due to the presence of significant quantities of cheaper semi-soft coals (Polish type 34) with weaker coking properties and the deficit of hard coals (Polish type 35) with the best coking properties - the missing amount of coals has to be imported.

The situation described above resulted in the fact that the coal charge pre-drying technology has become an object of extensive studies and analyses, and the concepts of its implementation have been considered by some Polish coking plants in recent years $[5,6,9$, $13,15]$. It also inspired the Institute for Chemical Processing of Coal in Zabrze (IChPW) to design the multi-stream dryer, which can be applied in the process of coal charge predrying. However, this dryer requires further research on an industrial scale. In this situation, a natural decision problem occurs whether to use a proven device (e.g. the CMC $2^{\text {nd }}$ generation indirect dryer) in an industrial-scale pre-drying operation or to conduct an industrial scale research of a multi-stream dryer designed by the IChPW. So defined, the issue can be presented and solved by the application of the proposed evaluation model of economic efficiency of the industrial scale research based on the discount method and the decision tree model [10]. 
Table 1. Basic technical, technological and economic assumptions for considered scenarios of coal charge pre-drying investment project in existing coking plant.

\begin{tabular}{|c|c|c|c|c|}
\hline \multirow[b]{2}{*}{ Item } & \multirow[t]{2}{*}{ Unit } & \multirow{2}{*}{$\begin{array}{c}\text { Coke plant } \\
\text { without } \\
\text { pre-drying }\end{array}$} & \multicolumn{2}{|c|}{ Coke plant with pre-drying } \\
\hline & & & $\begin{array}{l}\text { Dryer: indirect } \\
\text { II generation } \\
\text { CMC }\end{array}$ & $\begin{array}{c}\text { Dryer: multi- } \\
\text { stream designed by } \\
\text { ICHPW }\end{array}$ \\
\hline \multicolumn{5}{|c|}{ Technological data } \\
\hline $\begin{array}{l}\text { Production capacity } \\
\text { (wet base) }\end{array}$ & ths. $\mathrm{Mg} / \mathrm{a}$ & 3000 & 3208 & 3206 \\
\hline $\begin{array}{l}\text { Increase of production } \\
\text { capacity }\end{array}$ & $\%$ & - & 6,92 & 6,88 \\
\hline $\begin{array}{r}\text { Blend content recipe: } \\
\text {-semi-soft coal (type } \\
34) \\
\text {-hard coal (type 35) }\end{array}$ & $\begin{array}{c}\text { ths. } \mathrm{Mg} / \mathrm{a} \\
\% \\
\%\end{array}$ & $\begin{array}{l}10 \\
90\end{array}$ & $\begin{array}{l}20 \\
80\end{array}$ & $\begin{array}{l}25 \\
75\end{array}$ \\
\hline $\begin{array}{l}\text { Blend content } \\
\text { utilization: } \\
\text {-semi-soft coal (type 34) } \\
\text {-hard coal (type 35) }\end{array}$ & $\begin{array}{l}\text { ths. } \mathrm{Mg} / \mathrm{a} \\
\text { ths. } M g / a \\
\text { ths. } M g / a\end{array}$ & $\begin{array}{c}4062 \\
406 \\
3656\end{array}$ & $\begin{array}{c}4346 \\
869 \\
3477\end{array}$ & $\begin{array}{l}4346 \\
1087 \\
3260\end{array}$ \\
\hline \multicolumn{5}{|c|}{ Pre-drying installation characteristics } \\
\hline Type of dryer & - & - & Indirect & Direct \\
\hline Drying medium & - & - & Steam & $\begin{array}{c}\text { Coke oven gas } \\
\text { waste gases }\end{array}$ \\
\hline Number of devices & pieces & - & 3 & 5 \\
\hline Unit drying capacity & $\mathrm{Mg} / \mathrm{h}$ & - & 250 & 125 \\
\hline $\begin{array}{c}\text { Number of dryers in } \\
\text { operation }\end{array}$ & pieces & - & 2 & 4 \\
\hline $\begin{array}{l}\text { Preliminary moisture } \\
\text { content of charge }\end{array}$ & $\%$ & 9,5 & 9,5 & 9,5 \\
\hline $\begin{array}{c}\text { Moisture content after } \\
\text { pre-drying operation }\end{array}$ & $\%$ & - & 6,0 & 6,0 \\
\hline \multicolumn{5}{|c|}{ Economic data } \\
\hline $\begin{array}{r}\text { Total Capex } \\
\begin{array}{r}- \text { I year: } \\
- \text { II year: }\end{array}\end{array}$ & $\begin{array}{l}\text { Mil. } € \\
\text { Mil. } € \\
\text { Mil. } €\end{array}$ & - & $\begin{array}{l}80 \\
24 \\
56\end{array}$ & $\begin{array}{l}64 \\
24 \\
40\end{array}$ \\
\hline $\begin{array}{c}\text { Analysed lifetime } \\
\text { period }\end{array}$ & Years & - & 15 & 15 \\
\hline Loan share & $\%$ & - & 68 & 60 \\
\hline Loan gross interest rate & $\%$ & - & 4,5 & 4,5 \\
\hline Cost of equity & $\%$ & 8,0 & 8,0 & 8,0 \\
\hline
\end{tabular}

\subsection{Application of evaluation model of economic efficiency of the industrial scale research based on the example of coal charge pre-drying}

In the considered coking plant a decision is being analysed to launch a coal charge predrying installation for 4 top charging coke oven batteries with base production capacity equal to 3 million tonnes of wet coke per year. There are two possible scenarios of investment project implementation. The first scenario assumes an immediate decision to use the CMC $2^{\text {nd }}$ generation indirect dryer. The second scenario assumes conducting the industrial scale research of the pre-drying process with the application of the research station equipped with a multi-stream dryer designed by the IChPW with the drying capacity 
equal to $10 \mathrm{Mg} / \mathrm{h}$ of wet charge. The cost of conducting industrial research equals EUR 5 million. Based on the industrial research results, a decision concerning the choice of the dryer will be undertaken: either the CMC $2^{\text {nd }}$ generation indirect dryer or the multi-stream direct dryer designed by the IChPW. In both scenarios the investment period is 2 years. In the first year of investment works common for both types of dryers are performed with the capital expenditures of EUR 24 million and it does not determine the decision about the dryer choice. The industrial research is successful if it results in obtaining the capacity of the multi-stream dryer to prepare the pre-dried blend consisting of $25 \%$ of semi-soft coals and $75 \%$ of hard coals, allowing for the production of the same coke quality. On the basis of the expert analysis, the probability of success of $30 \%$ was assumed.

In the case of the CMC 2nd generation indirect dryer, the coal charge pre-drying installation consists of 3 devices with the capacity of $250 \mathrm{Mg} / \mathrm{h}$ each, two in operation and one spare. Whereas, in the case of the multi-stream direct dryer designed by the IChPW, the coal charge pre-drying installation contains 5 dryers, each with a capacity of $125 \mathrm{Mg} / \mathrm{h}$, four of which are in operation. The basic technical, technological and economic assumptions are presented in table no. 1.

Based on the presented main and additional detailed assumptions, the economic efficiency of each investment project scenario has been evaluated by using the discounting method with the application of the Free Cash Flow to Firm approach (FCFF). In the case of the scenario involving industrial research, in the calculations, the effect connected with expenditures on that research was taken into consideration. According to the considered decision problem, a decision tree has been developed. It is presented in Figure 2. Table 2 shows the calculation of NPV for each branch of the decision tree.

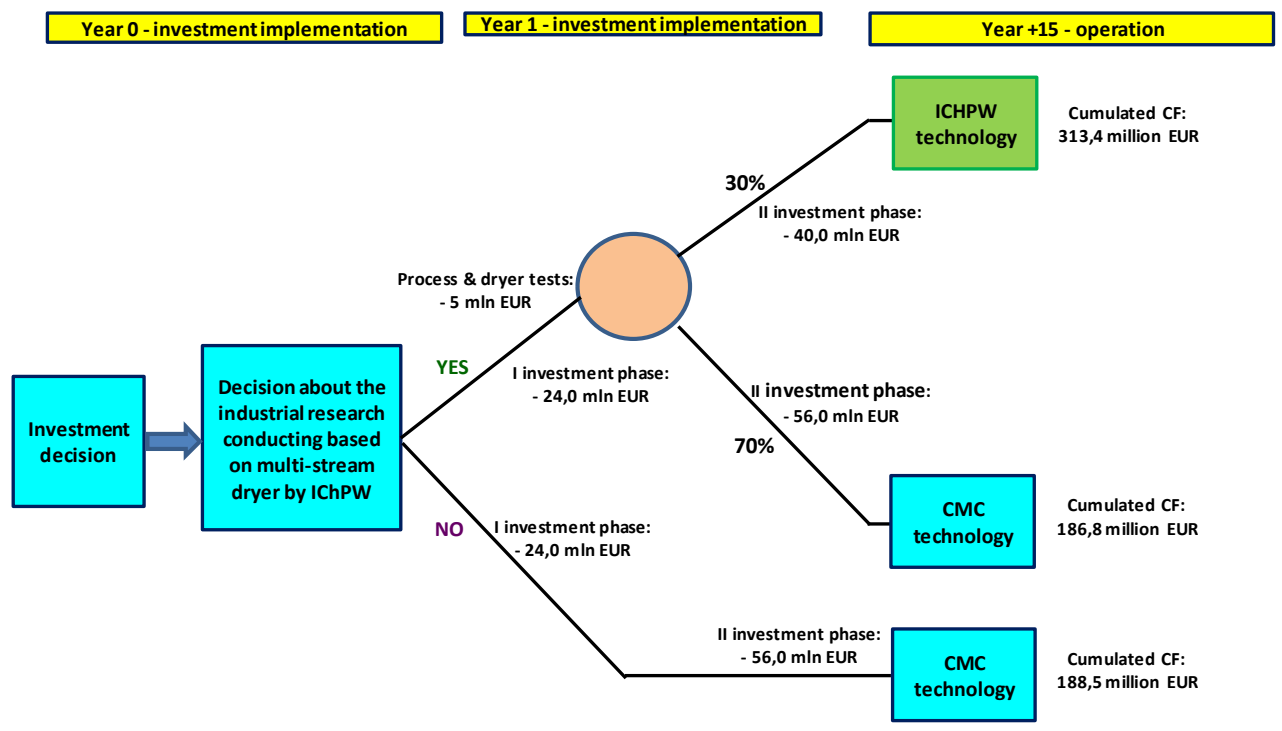

Fig. 2. Decision tree for investment project of pre-drying operation implementation in a coking plant preceded by conducting industrial research. 
Table 2. NPV determination for particular branches of the decision tree for the coal charge pre-drying operation implementation in a coking plant.

\begin{tabular}{|c|c|c|c|c|c|c|c|c|c|c|c|c|c|c|c|c|c|c|}
\hline \multirow{3}{*}{\multicolumn{2}{|c|}{ Item }} & & & & & & & & & & & & & & & \multicolumn{3}{|c|}{ [million EUR } \\
\hline & & 0 & 1 & 2 & 3 & 4 & 5 & 6 & 7 & 8 & 9 & 10 & 11 & 12 & 13 & 14 & 15 & 16 \\
\hline & & I1 & $\mathrm{I} 2$ & E1 & E2 & E3 & E4 & E5 & E6 & E7 & E8 & E9 & E10 & E11 & E12 & E13 & E14 & E15 \\
\hline \multirow{3}{*}{$\begin{array}{l}\text { Coal charge pre- } \\
\text { drying operation } \\
\text { with CMC II } \\
\text { generation dryer } \\
\text { application } \\
\text { without industrial } \\
\text { research } \\
\end{array}$} & FCF & $-24,0$ & $-56,0$ & 9,2 & 14,2 & 14,2 & 14,2 & 14,2 & 14,2 & 13,6 & 13,6 & 13,6 & 13,6 & 10,8 & 10,7 & 10,7 & 10,7 & 10,7 \\
\hline & $\mathrm{dFCF}$ & $-24,0$ & $-53,3$ & 8,4 & 12,3 & 11,7 & 11,1 & 10,6 & 10,1 & 9,2 & 8,7 & 8,3 & 7,9 & 6,0 & 5,7 & 5,4 & 5,1 & 4,9 \\
\hline & NPV & \multicolumn{17}{|c|}{48,0} \\
\hline \multirow{3}{*}{$\begin{array}{l}\text { Coal charge pre- } \\
\text { drying operation } \\
\text { with CMC II } \\
\text { generation dryer } \\
\text { application with } \\
\text { industrial } \\
\text { research } \\
\end{array}$} & FCF & $-29,0$ & $-56,0$ & 9,2 & 14,2 & 14,2 & 14,2 & 14,2 & 14,2 & 13,5 & 13,5 & 13,5 & 13,5 & 10,5 & 10,5 & 10,5 & 10,5 & 10,5 \\
\hline & $\mathrm{dFCF}$ & $-29,0$ & $-53,2$ & 8,3 & 12,2 & 11,6 & 11,0 & 10,5 & 10,0 & 9,0 & 8,6 & 8,1 & 7,7 & 5,7 & 5,4 & 5,2 & 4,9 & 4,7 \\
\hline & NPV & \multicolumn{17}{|c|}{40,6} \\
\hline \multirow{3}{*}{$\begin{array}{l}\text { Coal charge pre- } \\
\text { drying operation } \\
\text { with multi-stream } \\
\text { ICHPW dryer } \\
\text { application with } \\
\text { industrial } \\
\text { research }\end{array}$} & FCF & $-29,0$ & $-40,0$ & 17,4 & 22,4 & 22,4 & 22,4 & 22,4 & 22,4 & 21,8 & 21,8 & 21,8 & 21,8 & 19,4 & 19,4 & 19,4 & 19,4 & 19,4 \\
\hline & $\mathrm{dFCF}$ & $-29,0$ & $-37,9$ & 15,6 & 19,0 & 18,0 & 17,1 & 16,2 & 15,3 & 14,1 & 13,4 & 12,7 & 12,0 & 10,1 & 9,6 & 9,1 & 8,6 & 8,1 \\
\hline & NPV & \multicolumn{17}{|c|}{132,1} \\
\hline
\end{tabular}

Table 3 presents the determination of the expected value E (NPV) in the case of conducting industrial research.

Table 3. NPV determination for particular branches of the decision tree for the coal charge pre-drying operation implementation in a coking plant.

\begin{tabular}{|l|c|}
\hline \multicolumn{1}{|c|}{ Item } & NPV \\
\hline $\begin{array}{l}\text { Expected value of Project NPV E(NPV) in the case of conducting industrial } \\
\text { research and choice of the dryer based on it after 1 year }\end{array}$ & 68,05 \\
\hline $\begin{array}{l}\text { Project NPV in the case of immediate decision about choosing the II } \\
\text { generation CMC dryers }\end{array}$ & 47,99 \\
\hline
\end{tabular}

The economic efficiency evaluation results show that even with a low probability of obtaining positive results $(30 \%)$ of industrial research on the development of the multistream dryer, the decision to conduct the tests is economically justified. The expected value of E (NPV) for such a sequence of the project implementation exceeds by far the NPV for the scenario which determines the type of a dryer at the beginning of the project.

\section{Conclusions}

The practical application of evaluation model of economic efficiency of industrial research based on the decision tree and discounting shows that the industrial research generates a measurable value.

The presented model uses common and understandable evaluation techniques of investment projects, i.e. the decision tree model and discounting. Therefore, it is easy to use and understand by a wide group of stakeholders. Due to its versatility, it can be used in many areas. 


\section{References}

1. R. Budziński, University of Szczecin, Scientific methodology - unpublished lecture, (2011),

2. A. Czaplicki, Karbo, Pre-drying operation before coking process, special edition, 4757, 2007,

3. A. Czaplicki, M. Janusz, M. Kosewska, K. Wróblewska, Karbo, Coal blend preparation methods and their influence on coke quality in top charging system, 2, 8899, (2012),

4. Z. Frankl, J. Salcewicz, Coke, Tar \& Gas The heating rate as a factor in improving the coals sinterability, 6, (1961),

5. A. Karcz, (Reasearch project AGH) Research of coking coals pre-drying process in terms of assessing the possibility of extending the raw materials base for the production of high-quality coke, (2007),

6. A. Karcz, A. Strugała, Mineral Resources Management, Increasing chances of utilizing the domestic coking coal resources through technological operations in coal blend preparation, 24, 5-18 (2008),

7. B. Klepacki, Annals of agriculture science, The chosen problems connected with methodology of economic scientific research, 96, 38-46, (2009),

8. K. Kushioka, Y. Konno The Iron and Steel Institute of Japan, New Moisture Control System of Coal for Coking, (1985),

9. W. Latocha, W. Kaczmarek, A. Strugała, P. Żarczyński, Energy Policy Journal Extending the coal base of the Polish cokemaking industry through the implementation of the coal charge pre-drying and through the use of the overseas coals, 14, 215-229 (2011),

10. Patent: Patent Office Bulletin No. 24 (1041) - Application No P.399258 of 21.05.2012 (2013),

11. W. Pluta, Capital budgeting, (2000),

12. R. Poultney, R. Willmers, The Coke oven Managers' year-book 2000, Assessment of coal pre-treatment systems, (2000),

13. A. Sobolewski, A. Czaplicki, P. Żarczyński, Institute for Chemical processing of Coal in Zabrze, The conceptual design of the pilot coal charge pre-drying installatio for ArcelorMittal Poland SA Zdzieszowice Unit - unpublished, (2013),

14. P. Szczepankowski, WSPiZ Publisher, Company finance management (2004),

15. A. Tramer, M. Kosewska, K Wróblewska, A. Sobolewski The $1^{\text {st }}$ Polish-Czech Konference, Opportunities to improve the quality of coke by coal charge pre-drying, (2001),

16. P. Żarczyński, A. Strugała, A. Sobolewski, W. Kaczmarek, Mineral Resources Management, Evaluation of potential improvements to coking process energy efficiency as a consequence of implementing a coal blend pre drying operation, 29, 151-165, (2013), 